\title{
Instructional Design Model for Applying Flipped Learning in Higher Education Institutions
}

\author{
Dr. Mohd. Elmagzoub A. Babiker Eltahir \\ College of Education and Basic Sciences, Ajman University, Ajman, UAE
}

\begin{abstract}
The era of globalization, growth and development of information and communication technology (ICT) and its application to learning and teaching has influence on our modern generation students, making the teaching traditional methods are useless. Changing familiar instructing methods can be a challenge available for instructors as a way to ignite our students' curiosity and make our teaching materials more engaging and effective. Recently, the flipped learning model has been recognized by educators as an effective instructional approach (Hwang, \& Wang 2015), it is a pedagogical approach in which the typical lecture and activities elements of a course are reversed, where students individually watch online lectures prior to class and then engage in classroom learning activities interacting with peers and instructors. Flipped learning model helps instructor to focus more on student-centered learning, which includes any use of the technology to take advantage of learning in the classroom, so that the instructor can spend more time interacting with the students instead of lecturing. The purpose of this study is to suggest instructional design (ID) model for teaching undergraduate courses applying the flipped learning model. Research on ID models may be classified into three different types: model development, model validation, and model use. This study concerned the first one of these, and it is based on the ADDIE, Dick and Carey model. The process begins with planning, followed by programming, then Coaching. Assessing and evaluating occur continually throughout the process and act as valuable mechanisms for monitoring progress and identifying achievement. At each stage of the process, instructors base their decisions on the requirements of the course curriculum, and, equally importantly, on their students' needs.
\end{abstract}

Keywords: Flipped Learning, Flipped Classroom, Flipped Pillars, Information Communication Technology (ICT), Instructional Design (ID).

\section{Introduction}

Information Communication technologies play a more important role in the early part of the 21 st century than they have ever done before. There are a number of reasons for this. Technology is taking its rightful place in the society now, in the workplace, education, and home. In fact, the changes that are taking place all around us are due to the prevalence of technology in our environment. Information communication technologies are helping people to work faster, more intelligently, more efficiently and more productively than ever before (Collins, \& Halverson, 2010). However, the effect of the new technologies in our educational institutions is not as profound as it might be; there are still very many instructors who are uncomfortable in the ICT controlled environment (Marshall, \& Ruohonen, 2013; Inan, \& Lowther, 2010; Collins, \& Halverson, 2010). They prefer to use the traditional teaching aids even when multimedia application would be enjoyable and more effective class-teaching means. They still convinced that they are the only major source of knowledge and they are not admitting that instructors in modern classrooms are no longer lecturers, they are facilitators. They need to teach their learners how to gain information and how to select and use them. They need to implement student-centered learning approaches in their instruction (McCarthy, 2015). In addition, because "the whole education system is moving towards a better support of individual abilities and self-directed play a much bigger role than in the past" (Marshall, \& Ruohonen, 2013), they need to create a learning environment that supports individuals to learn what they need to know or to do. They need to integrate technology in their instructional design and classroom, just knowing how to use a computer and technology hardware is not enough. Instead, as Ertmer \& Ottenbreit (2010) said:

Teaching with technology requires instructors to expand their knowledge of pedagogical practices across multiple aspects of the planning, implementation, and evaluation processes. (Ertmer \& Ottenbreit 2010, p. 264) 
Higher Education institutions are facing the pressures from globalization and the development of information and communication technology (ICT), which demand experience with technology, different skills, and a different learning experience. These demands place higher education institutions in a difficult position, and to a certain extent they are forced to explore new delivery modes that accommodate learner needs in the 21st century. However, changing familiar teaching methods can be a challenge available for instructors as a way to ignite our students' curiosity and make our teaching materials more engaging and effective.

Recently, the flipped learning model has been recognized by educators as an effective instructional approach (Hwang, \& Wang 2015), (Brame, C. 2013), (Berrett D 2012). it is instructional approach helps instructor to focus more on studentcentered learning, which includes any use of the technology to take advantage of learning in the classroom, so that the instructor can spend more time interacting with the students instead of lecturing. It can improve learning by encouraging reflection instead of mere reaction, and by emphasizing results rather than attendance. Through communication, learning becomes an active process where everybody involved in the learning experience has to constantly contribute to the learning process by sharing his or her thoughts and ideas to the class discussion. Critical thinking and collaborative knowledge construction creates an empowering learning process.

The flipped learning model meets the needs of learners in the 21 st century, and facilitates a learning experience that equips learners with the necessary skills and attitudes (Lee, J., Lim, C. \& Kim, H. 2017). Higher education institutions can therefore justify investment in this delivery mode. But, instruction needs to be clarified, because not all instruction is effective, "Effective instruction is instruction that enables students to acquire specified skills, knowledge, and attitudes" (Reiser \& Dick, 1996). The role of instructor and what it can accomplish as well as its limitations must be understood.

This study suggests instructional design (ID) model for teaching undergraduate courses applying the flipped learning model. Research on ID models may be classified into three different types: model development, model validation, and model use. This study concerned the first one of these, and it is based on the ADDIE, Dick and Carey model. The process begins with planning, followed by programming, then Coaching. Assessing and evaluating occur continually throughout the process and act as valuable mechanisms for monitoring progress and identifying achievement. At each stage of the process, instructors base their decisions on the requirements of the course curriculum, and, equally importantly, on their students' needs.

\section{Core Concept}

First I will inspect four core concepts that are needed for this article: Instructional design, Flipped Learning, Flipped Classroom and Flipped Pillars.

\section{Instructional Design}

In general design is a systematic planning process prior to implementation. Or engineering something according to specific criteria and the term is used in many fields such as: decoration, interior design, engineering, industry, and trade. In the area of education, the instruction design is a modern science that has emerged in recent years of the twentieth century; it is concerned with understanding and improving the teaching and learning process. According to Gagné and Briggs (1974) instructional design augments learning by incorporating various strategies into courseware, for example structuring, ordering and sequencing content in particular ways, depending on the expected learning outcome. Seels and Glasgow (1998), state that "instructional design is the process of solving instructional problems by systematic analysis of the conditions for learning ."

Berger and Kam (1996), point out that instructional design is the systematic process of translating general principles of learning and instruction into plans for instructional materials and learning. Jonassen (2001) defines Instructional design as "the application of theory to create effective instruction". In today's world, with an emphasis of lifelong learning, instructional design is not merely an organized approach to product or course development. It is instead "a generic process for analyzing human performance problems and determining appropriate solutions to such problem" (Richley et al. 2001, p. 29).

According to Charles (1983) instructional design is concerned with understanding, and applying methods of instruction. It is the process of deciding what methods of instruction are best for bringing about desired changes in student knowledge and skills for specific course content. It can be the process of translating general principles of learning and instruction into plans for instructional materials and learning. It is the entire process of analysis of learning needs and goals through to the 
evaluation of the instructional program. Instructional design pays attention to instruction from the learner perspective than from the content perspective which is traditional approach (Isman, 2011). Instructional design is concerned with understanding, improving, and applying methods of instruction (Reigeluth, 2013).

Instructional design is a systematic approach to building a program, courses study units or lessons (Dick \& Carey, 2001). It provides one framework for the systematic design, development and management of educational material and program. This systematic model of instructional design is often referred to as ADDIE model because it consists of five phases analysis, design, development, implementation and evaluation.

\section{Flipped Learning in The Context of Flipped Classroom}

The Flipped Learning Network distinguishes between a Flipped Classroom and Flipped Learning. "These terms are not interchangeable. Flipping a class can, but does not necessarily, lead to Flipped Learning" (FLN, 2014). They believe that the flipped learning is the logical next step in the evaluation of the flipped classroom.

Flipped classroom pioneers Bergmann and Sams (2014) in their book Flipped Learning state that the original flipped classroom concept focused on delivering content and didn't ensure student-centered learning, "we want to be clear that what has popularly become known as flipped classroom is only one basic form of flipped learning model" (Bergmann and Sams 2014, p. 5). The commonly known definition of the flipped classroom is an instructional strategy aimed at the use of modern technology and the Internet in a way that allows the instructor to prepare the lesson through video clips or audio or other media files, for the students to watch in their homes at their own pace using their computers or their smart phones or tablet devices before attending a class, While the class is devoted to discussions, projects and doing homework. The video is a key element in this type of education where the instructor set up video clip and shared with the students in a website or social networking (Bergmann and Sams, 2012). Bishop and Verleger (2013) define a flipped classroom as "an educational technique that consists of two parts: interactive group learning activities inside the classroom, and direct computer-based individual instruction outside the classroom." Flipped Learning Network provides an excellent definition to what the flipped learning is:

Flipped Learning is a pedagogical approach in which direct instruction moves from the group learning space to the individual learning space, and the resulting group space is transformed into a dynamic, interactive learning environment where the educator guides students as they apply concepts and engage creatively in the subject matter. (Flipped Learning Network. 2014)

\section{Theoretical Frameworks for The Flipped Learning Model}

According to the limited researchers' review, the key elements of the flipped learning model are built on student-centered learning theories (Bishop, \& Verleger, 2013; Hamdan, McKnight, McKnight, \& Arfstrom, 2013), which based on constructivist learning theory (Attard, 2010). Constructivism, derived originally from the works of Piaget (1970), Bruner (1962, 1979), Vygotsky $(1962,1978)$, and Papert $(1980,1993)$, is both a philosophical and psychological approach based on social cognitivism that assumes that persons, behaviors and environments interact in reciprocal fashion (Schunk, 2012). The major theme behind constructivist theory is that learning is an active process during which learners construct new ideas or concepts based upon their current and past knowledge (Bruner, 2009). Modern theories of learning advocate the constructivist approach to learning, stressing that learning is a distinctive and personal process characterized by individuals developing knowledge and understanding by forming and refining concepts (Dick \& Carey, 2001). Learning environments should therefore be provided with multiple knowledge representations and varied cases and context so as to facilitate the exploration of systems, environments and artifacts. Giving learners a sense of ownership over their learning helps them to take responsibility.

According to constructivism theory: learners construct knowledge (rather than acquiring it) individually through their interactions with the environment (including other learners) based on their current as well as prior knowledge, authentic experience, mental structures, and beliefs that are used to interpret objects and events in relation to the context and environment in which learning takes place; the learner is an active processor of information and creator of personal knowledge; instruction is a process of supporting that construction; knowledge is not purely objective; and the instructor's major role is that of a facilitator of learning (Dick \& Carey, 2001). 
Constructivists put their emphasis on learning rather than instruction implying the need for rich learning environments for students to actively engage with the instructor as well as their peers and construct knowledge. Besides, constructivism requires the learning environment should be learner-centered (Anderson \& Kanuka, 1999). Student-centered learning environment is seen as a major enabling element in constructivism.

Since the common constructivist ground is that learning is the process of learners actively constructing knowledge, traditional instructional methods, such as demonstrating, encouraging memorization and imitation are deemed incompatible with this point of view. Some constructivists propose that people learn most things better by means of participative activities such as writing, computer games, or multimedia composition than through traditional methods of directly teaching content.

Proponents of constructivism point out that education has been biased towards objectivism, treating learners as passive vessels into which knowledge is poured (Glasersfeld, 1989; Jonassen, 1991; Biggs, 1996; Dick \& Carey, 2001; Bruner, 2009). However, instructors should take the role of coaches, facilitators, or even partners, with learners. It follows, as has been stated, that the goal of instructors should be the creation of environments that facilitate the construction of knowledge.

\section{Flip Pillars}

According to Hamdan, McKnight, McKnight, and Arfstrom (2013), flipped classroom must include the four pillars of flipped learning identified as the "four pillars of F-L-I-P", which are: Flexible Environment, Learning Culture, Intentional Content, and Professional Educator.

Flexible learning environments: where classroom or teaching space can be adapted and students choose when and where they learn, Teaching should be adapted to accommodate the specific needs of each learner. Instructors are also flexible in their expectations of student timelines for learning and how students are assessed.

A shift in learning culture: where "students move from being the product of teaching to the center of learning." The instructor no longer transmits information but rather facilitates and coaches students to explore topic in greater depth. They are supporters rather than educators. They provide an environment in which the learner feels valued and in receipt of learning which will be of benefits not only in the classroom context, but also in their lives outside of the classroom.

Intentional content: Instructors evaluate what they need to teach and what materials student should explore on their own outside of the classroom. They also decide on the methods of teaching and learning.

Professional educators: skill professional educators have the responsibility of setting the stage for successful learning. They "must determine when and how to shift direct instruction from the group to the individual learning space, and how to maximize the face-to-face time between instructors and students".

\section{Instructional Design Model Phases}

The instructional design model phases (Figure 1) presented here is based on the ADDIE model. The process begins with planning, followed by programming, and then Coaching. Evaluating occur continually throughout the process and act as valuable mechanisms for monitoring progress and identifying achievement. At each stage of the process, instructors base their decisions on the requirements of the course curriculum, and, equally importantly, on their students' needs.

The diagram below shows the process of Planning, Programming, Coaching, and Evaluating. The steps will be described in sequence below. 


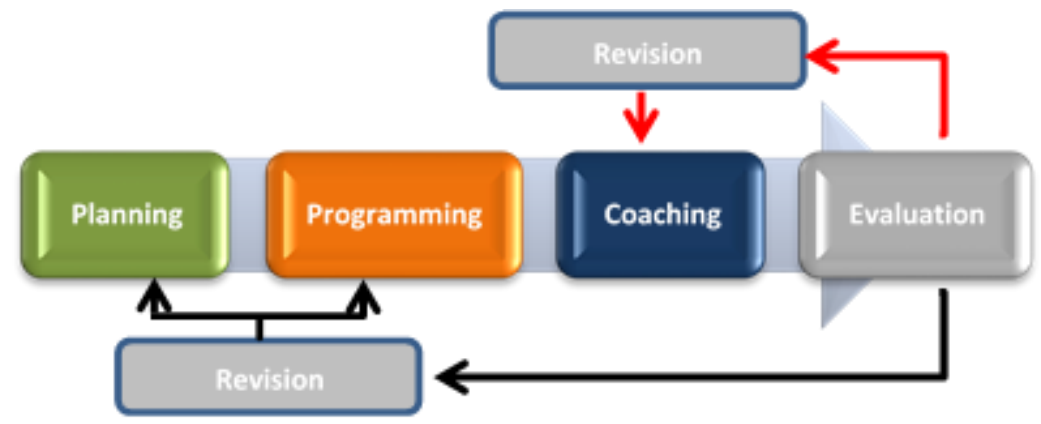

Figure 1: Instructional design model Phases

\section{Planning Phase}

Effective instructions don't come together by accident. They require planning and analysis. You'll produce the best instructional design if you first analyze tow important areas, see [Figure. 2]:

The analysis of learner characteristics.

The analysis of learning context

\section{The analysis of learner characteristics:}

One of the main focuses of flipped learning is the idea of individualized learning. "Flipped learning as its core, is individualized learning" (Bergmann and Sams ,2014:7). In order for there to be a chance of that happening, it's important to know who your learners are. Remember that we are not teaching to groups, but to groups of individuals. In addition to general characteristics such as age, grade level, and topic being studied, we should be able to describe our learners in terms of these characteristics as Dick and Carey (2001) pointed out:

Entry Behaviors: These are skills associated with learning the goal that must already be mastered. What should learners already know how to do in order to be successful with the new instruction? In the last lesson we determined specific entry behaviors related to our goal, but there may also be some general entry behaviors that were overlooked in the instructional analysis yet would be useful to mention at this point.

Prior Knowledge of the Topic Area: What must learners already know about the topic?

Attitudes toward Content and Potential Delivery System: What are the learners' impressions and attitudes about a topic and how it might be delivered? In other words, will they have any preconceived notions about the topic or the delivery system?

Academic Motivation: How motivated are learners to learn the topic, and how much is it likely to interest them? we might want to ask potential learners these questions :

How relevant is the instructional goal to you?

What aspects of the goal interest you most?

How confident are you that you could successfully perform the goal ?

How satisfying would it be to you to be able to perform the goal?

Educational and Ability Levels: What are the achievements and general ability levels of the learners? This helps determine the kinds of instructional experiences they may have had and their ability to cope with new and different approaches to instruction.

General Learning Preferences: What types of learning approaches do the learners prefer? For example, lecture, seminar, case study, small-group, or web-based? 
Attitudes toward Educational institutions: How do the learners feel about their educational institutions? Do they have a positive view of management, instructors and peers, or are they cynical about them? With instructors, we may already know our students' attitudes about school, but keep in mind that some students actually like school, while others may hate it. It's important to know which kind of students we will be interacting with.

Group Characteristics: Is there heterogeneity within the target population? If so, we want to make sure to accommodate any diversity. Also, get a general overall impression of the target population based on interactions with them .

That may seem like a lot of information to collect about our learners, but it can aid us immensely in providing more meaningful learning experiences for the learners. Some of it we may already know, but much of it should be culled by talking with learners, Colleagues, and parents. Other helpful methods include surveys, questionnaires, and pretests. Collecting this type of data may be much easier if we are instructor with a long experience, as we are already immersed in the environment, and thus may already know many of the students we will be teaching. However, don't immediately assume that we know the answers to these questions.

The list of learner characteristics we end up with will be used throughout the remainder of the instructional design process to make decisions regarding the various steps. It will help us determine the objectives (next step), as well as play a major role in the instructional strategies we employ later on .

\section{The analysis of learning context involves two steps:}

\section{Determining Instructional Needs :}

Dick and Carey (2001) state that "Perhaps the most critical event in the instructional design process is identifying goals" (Dick and Carey, 2001, p.17). Before establishing the instructional goals, instructors must analyze the learning environment and reflect on what has been done previously to identify the areas that should receive special emphasis in the course. The process, which is called "learners needs" or "needs analysis", consists of identifying the topics to be included, determining what it is that learners need to know, and data regarding student performance. Instructional goals are ideally to be derived through this analysis procedure .

For instructors needs analysis is often informal but is nevertheless very important. Such needs analysis can be directed at determining :

What are the major topics to be covered;

What portion of curriculum involves learning tasks that students had difficulty in learning and for which no readily available instructional solution exists; and

Which learning tasks, therefore, needs to be designed, modified or redesigned?

Needs analysis should also indicate whether there were learning goals that were not being reached previously. Such goals should then be candidates for the development of instruction. It should identify the areas of instruction that were not appealing, motivating, interesting and relevant to learners. These areas again should be considered for revision of the current instruction or instructional materials/tasks .

\section{Describing the Learning Environment}

By knowing a little bit about our learners we can better arrange the environment to increase the probability of individual student learning. The primary task of this analysis is to think about the environment in which the instruction will take place. It should enable us to analyze all factors that affect and are affected by the instruction that we will provide .

It is always wise to consider, beyond the classroom, the larger learning system into which the classroom environment belongs. The characteristics of the school and the community in which the instruction will take place are critical for the success of the implementation of our instruction .

It is important that instructors support each other and share their expertise, information and ideas throughout the teachinglearning cycle. Instructors also need access to a range of resources, ideas and solutions as they work through the process of planning. 
Planning takes time and involves detailed discussion, evaluation and review. It is important that schools make this time available to instructors. Planning is done both within learning area groups and across learning area groups, and across learning areas and grades. This whole-school approach ensures that teaching ideas and classroom experiences are shared and available to everyone when the programs and units of work are being developed. A whole school approach also develops good organizational practices and a thorough knowledge of the school Curriculum across learning areas.

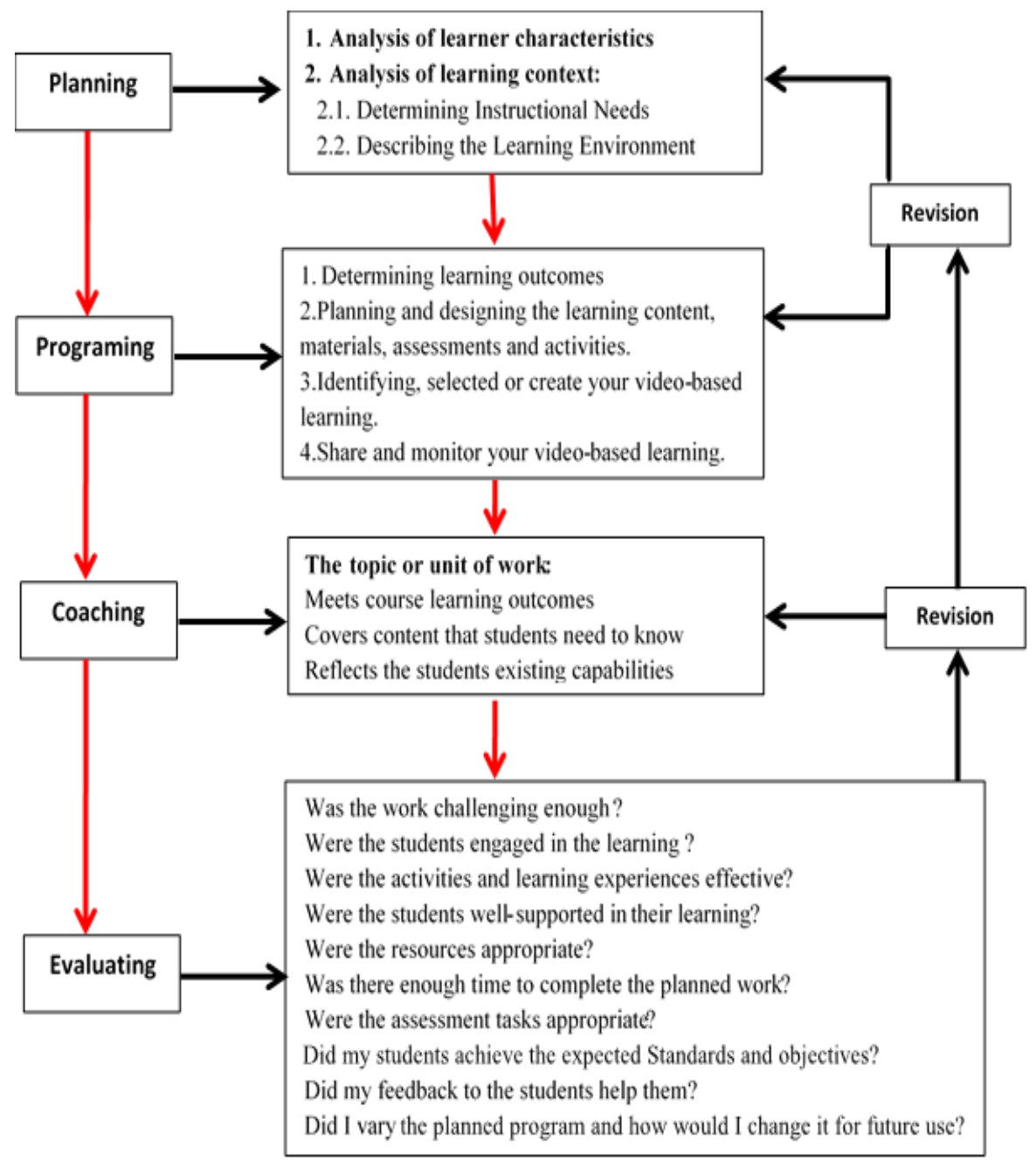

Figure 2: Instructional design model processes

\section{Programming Phase}

The Programming phase deals with learning outcomes, identifying the content, exercises, assessment strategies, learning activities and delivery mode. The Programming phase should be systematic and specific, see [Figure.2].

At the start of Programming phase, the instructor should have a pretty good idea of what the learners/students will already know when they start the course (through a learner analysis). The instructor should also know what learners will need to learn during the course (learning outcomes). 
How do you create a course that helps student move from what they already know and gain mastery of the new material? That's the question that the Programming phase process answers .

Steps in the Programming Phase:

There are basically four steps in Programming phase :

\section{Determining learning outcomes}

Planning and designing the learning content, materials, assessments and activities.

Identifying, selected or create your video-based learning.

Share and monitor your video-based learning.

\section{Determining learning outcomes:}

During the planning phase (a learner analysis), the instructor examines the learners' /students' current knowledge and capabilities. What do the students already know and have the ability to do? The instructor uses the information from the learner analysis to create a unit of work or a topic that focuses on students' actual needs.

We want a unit of work that challenges but doesn't overwhelm our students. If we don't take time to study the learners/students and their contexts, we could make a unit of work that bores students because it's too basic. We could also create a course that's impossibly difficult for a group of students - because it might assume that students know more than they really do. It is not only important to know what material we're going to teach, but also what our students need to be taught. Describe what the students will be able to do after having learnt this topic (i.e. learning outcomes and tasks they can do/perform) and list the relevant key/foundational concepts.

\section{Planning and designing the learning contents, assessments and activities.}

Learning activities are used in education because they facilitate effective communication, especially if it's educational technology tools (Danielson, 2011). They help learners to process and retain what they learn, as well as enhancing the instructor's credibility. Therefore, they should be simple, clear, active and professional. The learning contents or videobased learning used by instructor must enhance the learning, not replace it or distract from it. You must consider the topic, why you are flipping it, how this topic relates to capabilities that count? Identify established misconceptions around this topic and address these in the pre class activities and make links with assessment explicit.

Well-designed learning contents shorten coaching time and increase comprehension substantially. They can increase participation of learners, and facilitate group consensus.

\section{Identifying, selected or create your video-based learning:}

Technology must be used to improve the efficiency and effectiveness of the learning delivery process. This may be quite a change from traditional teaching procedure adopted by instructors. Individual and articulate vendors will make pitches for their own particular product, many of whom have contributed to the revolutionizing of IT teaching and training. Instructors must start by asking themselves a series of questions about technology and pedagogy: Will they make their own videos, curate others' material, or a combination of the two? (Bergmann, Sams 2012). There are plenty of good, educational videos from websites such as TED-Ed and Khan Academy, and online course sites such as edX, courser, and Alison allow you to get your students in. But, to achieve truly comprehensive educational goals, instructors must take the advantage of educational technology on the market. This means that instructors will have to create their own video-based learning. according to the learning outcomes and the topic that they cover. I absolutely agree with Babiker (2015) when he stated that: "Teachers must and need as educator to create their own multimedia applications if they really want to make use of the multimedia applications as an effective tool in education. When teachers create their own video-based learning they must remember to keep the lower-order things on Bloom's taxonomy to the videos and the higher-order things in class. (Bergmann, Sam 2012).

\section{Plan, share and monitor your video-based learning:}


In this step you have to plan how you are going to share your video, if you have a learning management system. All you need to do is upload the video and then add your students to the course. Another way is to create YouTube channel and upload it in. You can then monitor the activity to make sure everyone is logging in to view the material. You won't be able to monitor all student activity in real time from the learning management system or any other delivery media you choose, so you should set-up a mechanism that confirms the student has viewed the content. A simple end-of-lecture quiz (the points of which will be added to the activity), is a good place to start. This will also make it possible for you to deliver on the next step more effectively.

\section{Coaching Phase}

Gagne described instruction as asset of events external to the learner design to support the internal process of learning (Gagne, 1985). Samaldino state that "instruction is the arrangement of information and the environment to facilitate learning. This may be done by the learner or the instructor" (Smaldino, 2005). The learning styles of the learners must be taken into consideration in the Coaching Phase. Learning styles include the way a person perceives the world and new information, their unique experiences and the motivation they have for learning a particular topic (Gulid \& Garger, 1998; Fralick, 2011). It does not necessitate the design of customized topic for every learner, but it does require that every learner is accommodated and their learning needs catered for. The requirement for measurable results can only be met in this scenario. Only when instructor knows the base line can they judge what they have accomplished.

Research has shown that, the more involved and interested students are in what they are doing, the more they learn. Using learning strategies in which our students are 'saying and doing' improves their learning enormously (Smaldino, 2005), (Gulid \& Garger, 1998; Fralick, 2011), (Danielson, 2011). When we stand out the front of a room and lecture, our students' learning is far less effective, especially where this is our 'normal' teaching method.

The learning strategies we choose are important in ensuring that students are challenged and enjoy learning. They enjoy learning when that learning is relevant to them. They are also more likely to be challenged and engaged if they are actively involved in the learning activity. Tsai et al. (2015) state that "Flipped learning helps instructors move away from direct instruction as their primary teaching tool toward a more student-centered approach" (Tsai, et al., 2015, p.174). It is the learner who does the learning. Instructors can, of course, guide the process, but student develop understanding through what they do (Danielson, 2011).

In the 21st century instructors are facilitators of student learning and creators of productive classroom environments, the instructor acts as a coach when students are involved in project work or self-study. The instructor provides advice and guidance and helps students clarify ideas and limit tasks (Danielson, 2011).

Here are just some steps the instructor may use it during the coaching phase:

Set up the physical space to accommodate group based learning and organize learning resources

review student responses to the video, at the start of the class

Select the relevant concepts, related content and group learning activities e.g., case studies, flow charts, role play, quizzes, posters, which require students to apply and analyze the core concepts covered in the video

Support the class activities with planned mini lectures that introduce and/or summarize more complex concepts clarify remaining learning issues

deliver classroom learning activities and mini lectures as needed and 'time on task' - monitor allocated time dedicated to each classroom activity Summarize the learning segments by reviewing the learning outcomes.

But even more important than the coaching methods chosen is the attitude of the instructor which must emphatically be to promote independence among learners so that they can figure thing out for themselves when he is no longer available. In order to do this effectively, we as instructor must make the learner active in the learning process. We provide basic information, the concepts, the vocabulary and the skills, and then make the learner do the work! Ask more questions than we answer, and encourage them to answer their questions by progressing logically from the information and the skills we have delivered to them in the programming phase, and by using the resources (handouts, recorded video, web sites etc.). The rule of thumb is don't tell them how to do something, ask them how to do it. 


\section{Evaluation Phase}

This ID Process stresses the concept that good program requires planning, programming, review, and revision. Each of the three ID phases provides review checkpoints that allow the instructors to evaluate the work that has been produced so far .The ID evaluation phase can produce pretty graphs and metrics, but that's not its main purpose. The evaluation phase measures the program's efficacy and make sure that the students achieve the expected learning outcomes.

Mary Thorpe (1988) see evaluation as "the collection, analysis and interpretation on information about any aspect of a program of education and training, as part of a recognized process of judging its effectiveness, its efficiency and any other outcomes it may have" (Thorpe, 1988, p.5). Evaluation must be seen as an ongoing process that is initiated in the earliest stages of program planning and continued beyond program completion.

Each the instructional course should be accompanied by a well-designed evaluation plan for determining its effectiveness. Because of the complexity of current changes in education, this plan should extend over time in order to describe and give value to the interrelationship of individual change and systemic change in education. The development of the evaluation strategy should commence at the beginning of the planning process for each the instructional course.

As a preliminary step, evaluators determine the purposes of the evaluation. After the purposes of the evaluation are determined, the evaluators can plan the evaluation itself. The evaluation design should be based on the intended outcomes of the institutions-improvement effort. The evaluators can ensure the quality of the instructional system design process by asking questions that focus on the value of the program in achieving institutions -improvement goals and critiquing it with a short-term evaluation questions checklist.

\section{Evaluation Questions}

During the evaluation phase, the instructor measures how well the program, practices and strategies achieved its goals. Here are just some of the questions that might be explored during the evaluation phase .

Did the activities and learning experiences cater for the needs, ability levels and interests of all students?

Was the work challenging enough?

Were the students engaged in the learning?

Were the activities and learning experiences effective?

Were the students well-supported in their learning?

Were the delivery media appropriate?

Was there enough time to complete the planned work?

Were the assessment tasks appropriate?

Did my students achieve the expected outcomes?

Did my feedback to the students help them?

Did I vary the planned program and how would I change it for future use?

For some questions, it's fairly easy to collect information. You can find out students' opinions of the program through a short survey immediately after the class. A pre-test and post-test can measure how well students achieved the learning objectives .

\section{Summary \& Conclusion}

Instruction must be appropriate, and meet the needs of its target group, and it must be seen to be justified in terms of return on investment. In other words, it must be effective in changing the way students do thing so that efficiency and productive are improved. In my view, traditional lecturing methods in higher education institutions - needs to change in the near future. Some experts say it is too late to begin the changes, as we need new competencies in instructors right now. However, if 
our instruction methods remain practical, flexible and learner-centered, there is a hope that the next generation of learners will get the support and skills they need in their future life.

Flipped learning model appoints to increase motivation toward learning process, mimic reality and are consistent with its requirements, bringing this generation need to harness technology, to add excitement, suspense and curiosity for the multiple elements of the curriculum materials, classroom learning environment, and effective means of communication between the instructor and the learner and meet the individual and specific needs of each student. The flipped learning model meets the needs of learners in the 21st century, and facilitates a learning experience that equips learners with the necessary skills and attitudes for the 21 st century. Higher education institutions can therefore justify investment in this delivery mode. It's possible for someone to record a lectures in a video clips without following this instructional design methodology, but there's a much higher degree of risk. The lectures could have the wrong focus, confuse or frustrate the students, or even lack critical content. So, if the course has been developed without planning or programing, then all you can do is hope that the course will go well.

This Instructional design model provides a systematic methodology to plan, and program the unit of work or a course before it launches. If we follow this ID Process, we'll have a high degree of confidence about the course when it's ready to launch.

\section{References}

[1] Anderson, T., \& Kanuka, H. (1999). Using constructivism in technology-mediated learning: Constructing order out of the chaos in the literature. In Radical Pedagogy 1 (2), ICAAP. [online] Retrieved October 10, 2015 from http://citeseerx.ist.psu.edu/viewdoc/summary?doi=10.1.1.506.5182.

[2] Attard, A. (Ed.). (2010). Student Centered Learning an Insight into Theory and Practice. [online] Retrieved October 10, 2015 from http://www.esuonline.org/pageassets/projects/projectarchive/2010-T4SCL-Stakeholders-Forum-Leuven-An-Insight-IntoTheory-And-Practice.pdf

[3] Babiker, M. (2015). For Effective Use of Multimedia in Education, Teachers Must Develop their Own Educational Multimedia Applications. The Turkish Online Journal of Educational Technology (TOJET). October 2015, volume 14 issue 4, p. 62-68. Turkey.

[4] Bergmann, J., \& Sams, A. (2012). Flip your classroom: Reach every student in every class every day. Eugene, Or: International Society for Technology in Education.

[5] Bergmann, J., \& Sams, A. (2014). Flipped Learning: Gateway to Student Engagement: International Society for Tech in Ed.

[6] Biggs, J. (1996). Enhancing teaching through constructive alignment. Higher education, 32(3), 347-364 .

[7] Bishop, J. L., \& Verleger, M. A. (2013). The flipped classroom: A survey of the research. ASEE Annual Conference \& Exposition, Paper ID\#6219.

[8] Brame, C., (2013). Flipping the classroom. Vanderbilt University Center for Teaching. Retrieved October 23, 2015 from http://cft.vanderbilt.edu/guides-sub-pages/flipping-the-classroom/.

[9] Berrett $D$ (2012). How 'flipping' the classroom can improve the traditional lecture. The Chronicle of Higher Education, Feb. 19, 2012.

[10] Bruner, J. S. (2009). The Process of Education, Revised Edition: Harvard University Press.

[11] Collins, A., \& Halverson, R. (2010). The second educational revolution: Rethinking education in the age of technology. Journal of computer assisted learning, 26(1), 18-27.

[12] Danielson, C. (2011). Enhancing professional practice: A framework for teaching. ASCD.

[13] Dick, Walter \& Carey, Lou. (2001). The Systematic Design of Instruction. Fifth Edition. Longman., New York USA .

[14] Duffy, T.M. \& Jonassen, D.H. (1992). Constructivism and the Technology of Instruction. Lawrence, New Jersy USA.

[15] Ertmer, P. A., \& Ottenbreit-Leftwich, A. T. (2010). Instructor technology change: How knowledge, confidence, beliefs, and culture intersect. Journal of research on Technology in Education, 42(3), 255-284.

[16] Flipped Learning Network. (2014). What is flipped learning? Retrieved October 15, 2015, From http://fln.schoolwires.net//site/Default.aspx?PagelD=92

[17] Fralick, M. (2011). College \& career success (5th ed.). Dubuque, lowa: Kendall/Hunt Pub.

[18] Fulton, K. (2012). Upside down and inside out: Flip your classroom to improve student learning. Learning \& Leading with Technology, 39, (8),12-17

[19] Gagne, R.M.; Briggs, L.J.; Wager, W.W.; Golas, Katharine C.; \& Keller, John M. (2005). Principles of Instructional Design. Wadsworth USA .

[20] Glasersfeld, E. V. (1989). Constructivism in education. The international encyclopedia of education, 1,162-163.

[21] Guild, P. B., \& Garger, S. (1998). Marching to different drummers (2nd ed.). Alexandria, Va.: Association for Supervision and Curriculum Development. 
[22] Gustafson, K.L. (1996). International Encyclopedia of Educational Technology. Edited by Plomp, T. \& Ely, A.P. Pergamon, USA.

[23] Hamdan, N., McKnight, P., McKnight, K., \& Arfstrom, K. M. (2013). A review of flipped learning. Flipped Learning Network.

[24] Hilbert, M. (2014), Technological information inequality as an incessantly moving target: The redistribution of information and communication capacities between 1986 and 2010. Journal of the Association for Information Science and Technology, 65: 821-835.

[25] Hwang, G. J., Lai, C. L., \& Wang, S. Y. (2015). Seamless flipped learning: a mobile technology-enhanced flipped classroom with effective learning strategies. Journal of Computers in Education, 2(4), 449-473.

[26] Inan, F. A., \& Lowther, D. L. (2010). Factors affecting technology integration in K-12 classrooms: A path model. Educational Technology Research and Development, 58(2), 137-154.

[27] Jonassen, D. H. (1991). Objectivism versus constructivism: Do we need a new philosophical paradigm? Educational technology research and development, 39(3), 5-14.

[28] Keengwe, J., Onchwari, G., \& Oigara, J. N. (2014). Promoting active learning through the flipped classroom model. Hershey, PA: Information Science Reference.

[29] Kemp, J.E.; Morrison, G.R. \& Ross, S.M. (1994). Designing Effective Instruction. Merill, New York USA. McGriff, J.S. (2001). ISD Knowledge Base / Behaviorism. [online] Retrieved October 10, 2015 from http://www.personel.psu.edu

[30] Kirschner, P., Sweller, J. and Clark, R. E. (2006). Why minimally guided learning does not work: An analysis of the failure of discovery learning, problem-based learning, experiential learning and inquiry-based learning. Educational Psychologist. 41(2), 75-86.

[31] Lee, J., Lim, C. \& Kim, H. Education Tech Research Dev (2017) 65: 427. doi:10.1007/s11423-016-9502-1

[32] Marshall, G., \& Ruohonen, M. (2013). Capacity Building for IT in Education in Developing Countries: IFIP TC3 WG3.1, 3.4 \& 3.5 Working Conference on Capacity Building for IT in Education in Developing Countries 19-25 August 1997, Harare, Zimbabwe: Springer US.

[33] McCarthy, J. (2015, September 9). Student-Centered Learning: It Starts with the Instructor. Retrieved October 9, 2015, from http://www.edutopia.org/blog/student-centered-learning-starts-with-instructor-john-mccarthy

[34] McGriff, J.S. (2001). ISD Knowledge Base / Cognitivism. URL http://www.personel.psu.edu. Retrieved on October 102015 .

[35] Norris, P. (2001). Digital Divide: Civic Engagement, Information Poverty and the Internet Worldwide. Cambridge University Press.

[36] Reigeluth, C. M. (Ed.). (2013). Instructional design theories and models: An overview of their current status. Routledge.

[37] Reiser, Robert A. \& Dick, Walter. (1996). Instructional Planning: A guide for instructors. Allyn and Bacon, Boston USA .

[38] Sams, A. \& Bergmann, J. (2013). Flip Your Students' Learning. Educational Leadership. March 2013. Vol. 70. No. 6. Pp. 1620. [online] Retrieved October 10, 2015 from http://www.ascd.org/publications/educationalleadership/mar13/vol70/num06/Flip-Your-Students'-Learning.aspx

[39] Schunk, D. (2012). Learning theories: An educational perspective (6th ed.). Boston: Pearson.

[40] Seels, Barbara B. (1995). Instructional Design Fundamentals. Educational Technology Publications, Englewood Cliffs, New Jersy USA.

[41] Smaldino, S. E. (2005). Instructional technology and media for learning (8th ed.). Upper Saddle River, N.J.: Pearson/Merrill/Prentice Hall.

[42] Thorpe, M. (1988). Evaluating open and distance learning. Harlow: Longman.

[43] Tsai, C. Y., Chang, C. T., Hsu, J. M., Tsai, H. H., Dai, Z. C., \& Yu, P. T. (2015). Toward a Highly Interactive Model of Flipped Learning. In Hybrid Learning: Innovation in Educational Practices (pp. 173-186). Springer International Publishing. 